\title{
HAMBATAN KOMUNIKASI INTERNAL DI ORGANISASI PEMERINTAHAN
}

\author{
Dwi Harivarman \\ Fakultas Ilmu Sosial dan Politik, Universitas Airlangga, Jalan Airlangga 4-6 Surabaya \\ 60286, Indonesia. No. Hp. 081311259963 , \\ E-mail: doeihem@gmail.com
}

\begin{abstract}
The Budget Execution Evaluation and Monitoring Program owned by the Ministry of Finance's Directorate of Budget Execution has a strategic role in safeguarding the implementation of the Ministry atau Institution budget so that the Indonesian Budget (APBN) can run more optimally. The smoothness of the program depends on the effective communication system at the time of program implementation. This study aims to determine the internal communication barriers in the Directorate of Budget Execution that should be removed for effective communication can occur in the implementation of The Budget Execution Evaluation and Monitoring Program. The research uses descriptive qualitative method with case study, where data is obtained through in-depth interview and observation of informants (officials and staff at Directorate of Budget Execution). The result of the research shows that the internal communication barrier faced by the Directorate of Budget Execution is the difference of perception between the leader and the subordinate about the implementation of the activity, the limited sharing of information practice from the management to the staff, and the leadership style that influences the implementation of the program activity.
\end{abstract}

Keywords: effective communication, communication barrier, government organization

\begin{abstract}
Abstrak
Program Monitoring dan Evaluasi Pelaksanaan Anggaran yang dimiliki oleh Direktorat Pelaksanaan Anggaran Kementerian Keuangan memiliki peran strategis dalam menjaga pelaksanaan anggaran Kementerian atau Lembaga agar pelaksanaan APBN dapat berjalan lebih optimal. Kelancaran program tersebut salah satunya bergantung pada sistem komunikasi yang efektif pada saat pelaksanaan program menjadi kegiatan. Penelitian ini bertujuan untuk mengetahui hambatan komunikasi internal organisasi Direktorat Pelaksanaan Anggaran yang harus dihilangkan agar komunikasi yang efektif dapat terjadi pada pelaksanaan program Monitoring dan Evaluasi Pelaksanaan Anggaran. Penelitian menggunakan metode kualitatif deskriptif dengan studi kasus, dimana data diperoleh melalui wawancara mendalam (in-depth interview) dan observasi terhadap informan (pejabat dan pegawai pada Direktorat Pelaksanaan Anggaran). Hasil penelitian menunjukkan hambatan komunikasi internal yang dihadapi oleh Direktorat Pelaksanaan Anggaran adalah adanya perbedaan persepsi antara pimpinan dan bawahan terhadap pelaksanaan kegiatan, terbatasnya praktik sharing informasi dari pihak manajemen kepada pegawai pelaksana, dan gaya kepemimpinan atasan yang berpengaruh dalam pelaksanaan kegiatan.
\end{abstract}

Kata kunci: komunikasi efektif, hambatan komunikasi, organisasi pemerintah

\section{Pendahuluan}

Sesuai dengan amanat konstitusi, Anggaran Pendapatan dan Belanja Negara (APBN) merupakan wujud pengelolaan keuangan negara yang dilaksanakan secara terbuka dan bertanggung jawab serta digunakan sebesar-besarnya untuk kemakmuran rakyat. Enam tahun terakhir terjadi peningkatan dalam jumlah belanja pemerintah yang menunjukkan adanya kemauan pemerintah untuk terus meningkatkan kontribusinya terhadap perekonomian (http: atau atau www. djpbn.kemenkeu.go.id atau portal atau id atau berita atau 131-artikel-ulasan-opini atau 1737-cahaya-spending-review.html, diakses pada tanggal 19 Oktober 2016). Untuk melihat 
kualitas dari belanja pemerintah tersebut, perlu dilihat pengaruhnya terhadap setidaknya tiga indikator kesejahteraan masyarakat yaitu Indeks Pembangunan Manusia (IPM), Kemiskinan, dan Rasio Gini (Spending Review Direktorat PA, 2015). IPM merupakan gambaran kondisi masyarakat dihitung berdasarkan kriteria pendidikan, kesehatan, dan standar hidup. Kemiskinan merupakan kondisi seseorang yang tidak dapat memenuhi kebutuhan dasarnya seperti makanan, pakaian, dan tempat berlindung sedangkan rasio digunakan sebagai gambaran untuk melihat distribusi pendapatan masyarakat.

Berdasarkan data dari Badan Pusat Statistik dan hasil laporan Belanja Pemerintah (Spending Review) Tahun 2015 oleh Direktorat Pelaksanaan Anggaran Kementerian Keuangan, belanja pemerintah masih belum optimal dalam meningkatkan kesejahteraan masyarakat dilihat dari data ketiga indikator kesejahteraan masyarakat tersebut. Program monitoring dan evaluasi yang diterapkan secara berkala sangat diperlukan terhadap pelaksanaan anggaran Kementerian atau Lembaga agar pelaksanaan APBN dapat berjalan lebih optimal.

Penerapan program monitoring dan evaluasi pelaksanaan anggaran ini salah satunya dilakukan oleh Direktorat Pelaksanaan Anggaran (Direktorat PA) yang merupakan salah satu unit eselon II pada Ditjen Perbendaharaan Kementerian Keuangan, dimana berdasarkan Peraturan Menteri Keuangan Republik Indonesia Nomor 234 atau PMK.01 atau 2015 tentang Organisasi dan Tata Kerja Kementerian
Keuangan diberi tugas dan fungsi terkait pelaksanaan anggaran pemerintah. Fungsi dari Direktorat PA meliputi antara lain perumusan dan pelaksanaan kebijakan di bidang pelaksanaan anggaran, pembinaan di bidang pelaksanaan anggaran, monitoring dan evaluasi pelaksanaan anggaran, penyusunan review belanja pemerintah (spending review) dan review pelaksanaan anggaran, serta pelaksanaan komunikasi, publikasi, dan edukasi pelaksanaan anggaran kepada kementerian atau lembaga.

Direktorat PA memiliki peran yang penting terhadap kualitas pelaksanaan anggaran Kementerian atau Lembaga karena memiliki fungsi pembinaan, monitoring dan evaluasi, serta edukasi terkait pelaksanaan anggaran kepada Kementerian atau Lembaga yang diwujudkan antara lain dengan pelaksanaan kegiatan Spending Review (SR) dan Evaluasi Pelaksanaan Anggaran Kementerian atau Lembaga (EPA $\mathrm{K}$ atau L) yang telah dirintis oleh Direktorat PA sejak tahun 2013. Rangkaian kegiatan SR dan EPA $\mathrm{K}$ atau $\mathrm{L}$ ini terdiri dari penyusunan laporan Spending Review atau Reviu Belanja Pemerintah pada awal tahun yang kemudian dilanjutkan dengan penyusunan laporan Evaluasi Pelaksanaan Anggaran Kementerian atau Lembaga pada setiap triwulan tahun anggaran. Dengan pentingnya peran dari Direktorat PA tersebut, maka salah satu faktor yang perlu diperhatikan untuk kelancaran pelaksanaan kegiatan SR dan EPA K atau L adalah jalannya proses komunikasi internal yang terjadi selama pelaksanaan kegiatan.

Komunikasi internal dalam dimensi komunikasi organisasi adalah proses 
komunikasiyangterjadiantaraanggotadalam organisasi, untuk kelancaran pelaksanaan kegiatan organisasi. Lawrence D. Brennan (dalam Effendy, 2011: 122), mendefinisikan komunikasi internal sebagai pertukaran gagasan (secara horizontal dan vertikal) di antara para administrator dan karyawan dalam suatu perusahaan atau organisasi guna terwujudnya tujuan perusahaan. Pertukaran gagasan atau informasi dalam komunikasi internal ditunjang oleh beberapa bentuk jalur komunikasi, antara lain komunikasi vertikal, horizontal, dan diagonal (Effendy, 2011: 123).

Kurang berhasilnya komunikasi dalam organisasi disebabkan antara lain karena karakteristik sifat dinamis yang dimiliki oleh organisasi, dimana organisasi merupakan sebuah sistem terbuka yang terus menerus mengalami perubahan karena selalu menghadapi tantangan baru dari lingkungan sekitar dan perlu menyesuaikan diri dengan keadaan lingkungan yang selalu berubah tersebut (Muhammad, 2011). Keadaan lingkungan yang dimaksud dapat berasal dari lingkungan internal maupun eksternal organisasi, dan dapat mempengaruhi proses komunikasi dalam organisasi yang kemudian juga berpengaruh terhadap pelaksanaan kegiatan organisasi untuk mencapai tujuan yang telah ditetapkan. Salah satu unsur dari lingkungan internal adalah faktor pimpinan organisasi dan gaya kepemimpinan dalam organisasi. Dalam penelitian Sarwani (2015) terhadap kinerja pegawai di instansi pemerintah daerah, diperoleh hasil bahwa gaya kepemimpinan dan strategi komunikasi memiliki pengaruh terhadap kinerja pegawai. Seorang pimpinan harus memiliki rencana dan strategi yang dapat dikomunikasikan kepada anggota organisasi, untuk dapat mewujudkan kinerja yang efektif. Ini sejalan dengan yang disampaikan oleh Fiedler dan Garcia dalam Rivai (2008: 21) bahwa seorang pimpinan akan memperoleh kinerja kelompok yang efektif dengan pertama-tama membuat rencana keputusan dan strategi yang efektif, kemudian mengkomunikasikannya lewat perilaku pengarah yang direktif.

Selain faktor pimpinan, faktor pesan dan cara penyampaian pesan juga mempengaruhi jalannya komunikasi dalam organisasi. Hal ini disampaikan oleh Syasyikirana (2013) yang meneliti tentang strategi komunikasi pasca terjadinya restrukturisasi pada manajemen organisasi. Penggabungan media lisan dan tulisansertagambardilakukanagarkomunikasi dapat berjalan lebih efektif. Pemilihan pesan juga disesuaikan dengan sasaran penerima pesan pada saat terjadi komunikasi oral secara tatap muka. Komunikasi secara tatap muka menjadi penting, sebagaimana yang disampaikan oleh Effendy (2011) bahwa dalam komunikasi persona tatap muka tanggapan komunikan dapat segera diketahui. Jenis komunikasi ini juga dianggap sebagai komunikasi efektif untuk mengubah sikap, pendapat, dan perilaku seseorang. Faktor lain yang dapat mempengaruhi jalannya komunikasi organisasi adalah keterbatasan informasi yang disampaikan pimpinan serta tidak adanya tanggapan atau feedback dari karyawan, karena hal tersebut dapat menjadi hambatan komunikasi ke bawah dari atasan ke bawahan (penelitian Johanna, 2013). 
Untuk dapat mengelola dan meminimalisir permasalahan atau hambatan yang disebabkan oleh keadaan lingkungan internal organisasi dalam proses komunikasi organisasi, diperlukan suatu komunikasi yang efektif. Suatu kegiatan komunikasi dikatakan berjalan secara efektif jika antara lain tujuan dari kegiatan komunikasi tersebut tercapai. Pace, Peterson, dan Burnett (dalam Effendy, 2011: 32) menyatakan bahwa tujuan utama kegiatan komunikasi adalah untuk memastikan komunikan memahami makna dari pesan yang diterima (to secure understanding), terus memelihara dan membina penerimaan tersebut (to establish acceptance), dan memotivasi komunikan untuk melakukan suatu kegiatan (to motive action). Hal senada juga disampaikan Ludlow dan Panton (1996) bahwa ukuran manajemen komunikasi yang efektif adalah bahwa informasi disampaikan dan hubungan dibangun dari penyampaian informasi tersebut.

Praktik komunikasi efektif dalam organisasi diterapkan dalam kegiatan koordinasi antar unit dalam organisasi. Koordinasi tersebut dibutuhkan karena antar individu dan unit dalam organisasi merupakan bagianbagian yang saling bergantung satu sama lain dalam pelaksanaan kegiatan organisasi. Dan koordinasi memerlukan komunikasi, terutama dari pihak manajemen organisasi. Dalam pelaksanaan koordinasi untuk mencapai komunikasi yang efektif tersebut, seringkali organisasi menghadapi hambatan-hambatan dalam proses komunikasi di lapangan. Hambatan tersebut oleh ahli komunikasi biasa disebut sebagai distorsi, dimana Ludlow dan
Panton (1996: 13) menyampaikan bahwa hambatan atau kendala dalam berkomunikasi akanselaluadadalamsetiap proses komunikasi. Terkait dengan distorsi dalam berkomunikasi, Ron Ludlow dan Fergus Panton (1996: 13) menyampaikan bahwa hambatan atau kendala dalam berkomunikasi akan selalu ada dalam setiap proses komunikasi. Penyebab terjadinya distorsi dalam komunikasi sehingga komunikasi menjadi tidak efektif antara lain adalah status effect, semantic problems, perceptual distortion, cultural differences, physical distraction, poor choice of communication channel, dan no feedback.

Untuk kelancaran pelaksanaan kegiatan SR dan EPA K atau L, Direktorat PA telah melakukan beberapa bentuk komunikasi internal (sosialisasi, pengarahan, rapat koordinasi, surat keputusan, nota dinas, surat tugas) yang ternyata masih belum berjalan dengan baik dan hasilnya belum optimal. Dengan pentingnya kegiatan Direktorat PA serta agar dapat memastikan komunikasi yang efektif terjadi selama pelaksaaan kegiatan SR dan EPA K atau $\mathrm{L}$, maka penelitian ini bertujuan untuk mengetahui hambatan komunikasi yang terjadi dalam internal organisasi Direktorat PA Kementerian Keuangan pada kegiatan SR dan EPA K atau L. Hasil penelitian ini diharapkan dapat dimanfaatkan sebagai bahan masukan bagi Direktorat PA Kementerian Keuangan serta menambah literatur di bidang komunikasi organisasi khususnya organisasi pemerintahan.

Penelitian ini melihat hambatanhambatan yang terjadi di Direktorat Pelaksanaan Anggaran Kementerian 
Keuangan pada pelaksanaan Program Monitoring dan Evaluasi Pelaksanaan Anggaran Kementerian atau Lembaga.

\section{Metode Penelitian}

Penelitian ini menggunakan pendekatan deskriptif dengan data kualitatif yang bermaksud mendeskripsikan hasil penelitian dan berusaha menemukan gambaran menyeluruh mengenai suatu keadaan. Pendekatan deskriptif dengan data kualitatif digunakan untuk memahami dan mempelajari masyarakat dalam kehidupan sehari-harinya, dengan tujuan untuk mengidentifikasi bagaimana pengalaman dan perilaku mereka dibentuk oleh konteks kehidupan mereka, seperti kehidupan sosial, ekonomi, budaya dan konteks fisik dalam kehidupan mereka (Hennik, Hutter, 2011: 9). Penelitian deskriptif diharapkan menjawab secara lebih terperinci mengenai gejala sosial yang dimaksudkan dalam suatu permasalahan penelitian yang bersangkutan (Manasse Malo, 1996: 39). Tipe penelitian ini diharapkan peneliti akan menghasilkan deskripsi yang akurat mengenai hambatan komunikasi internal organisasi Direktorat PA.

Metode penelitian menggunakan studi kasus, karena peneliti membutuhkan jawaban atas pertanyaan "bagaimana" atau "mengapa" suatu fenomena berlangsung, untuk menjawab pertanyaan penelitian berupa apa, kenapa, dan bagaimana (Yin, 2014: 38). Data dan informasi penelitian dikumpulkan melalui wawancara mendalam (in-depth interview) dengan para informan yaitu pegawai di level operatif (pelaksana) dan pegawai di level manajerial (kepala subdit dan kepala seksi)
Direktorat PA. Wawancara dilakukan dengan menggunakan pedoman wawancara sebagai panduan dalam mengajukan pertanyaan yang berkaitan dengan obyek penelitian yaitu hambatan-hambatan yang terjadi secara internal organisasi Direktorat PA dalam pelaksanaan Program Monitoring dan Evaluasi Pelaksanaan Anggaran, namun tetap fleksibel tergantung pada perkembangan dan situasi dalam wawancara. Selain itu, observasi juga dilakukan terhadap pegawai Direktorat PA dan lingkungan kerja pada proses komunikasi di internal organisasi, untuk mencatat hal, perilaku, perkembangan, dan lain sebagainya terkait perilaku dan tindakan yang terjadi di lingkungan pada saat proses penelitian. Data tambahan diperoleh dari pengumpulan data sekunder melalui metode online maupun offline berupa dokumen, literatur, artikel, jurnal, dokumentasi, arsip publikasi kegiatan, tautan situs internet, dan lainnya yang terkait dengan permasalahan penelitian dan mendukung analisis penelitian.

Proses analisis data dilakukan dengan teknik analisis data kualitatif menurut Marshall dan Rossman (1995), dimana dalam proses menganalisis penelitian kualitatif terdapat beberapa tahapan yang perlu dilakukan, diantaranya adalah: (1) mengorganisasikan data; (2) pengelompokkan data; dan (3) analisis secara naratif dengan tema hambatan komunikasi dalam lingkup komunikasi organisasi.

\section{Hasil Penelitian dan Pembahasan}

Suatu proses komunikasi dikatakan berhasil jika pesan atau makna yang disampaikan oleh komunikator diterima secara lengkap dan utuh oleh komunikan 
serta dipahami dan dimaknai secara tepat oleh komunikan, layaknya pemahaman atau persepsi dari komunikator. Namun ada kalanya proses komunikasi tersebut tidak berjalan dengan lancar karena adanya distorsi yang akhirnya dapat menghambat jalannya proses komunikasi tersebut. Distorsi atau hambatan komunikasi ini juga terjadi di Direktorat Pelaksanaan Anggaran Kementerian Keuangan pada pelaksanaan Program Monitoring dan Evaluasi Pelaksanaan Anggaran. Dengan peran dan manfaat program tersebut yang strategis dalam menjaga dan mengawal pelaksanaan anggaran dari Kementerian atau Lembaga serta pelaksanaan APBN, maka diperlukan komunikasi yang efektif untuk kelancaran pelaksanaan kegiatan dan program tersebut. Untuk memperoleh komunikasi yang efektif tersebut, maka perlu diketahui hambatanhambatan apa saja yang terjadi atau muncul pada pelaksanaan program tersebut di lapangan sehingga dapat dilakukan langkahlangkah untuk dapat meminimalkan distorsi komunikasi tersebut.

\section{Hambatan Komunikasi}

Dalam proses komunikasi yang terjadi selama pelaksanaan Program Monitoring dan Evaluasi Pelaksanaan Anggaran, ditemukan adanya perbedaan persepsi antara pimpinan dan bawahan terhadap pelaksanaan kegiatan tersebut. Pimpinan Direktorat PA yaitu direktur dan pejabat di level manajerial, menggunakan strategi mengedepankan pencapaian visi dan misi organisasi dalam melakukan komunikasi dengan para bawahan. Strategi tersebut dilakukan setiap saat, baik pada saat pengarahan oleh direktur maupun saat koordinasi untuk pelaksanaan suatu kegiatan. Dari hasil observasi di lapangan dan hasil wawancara dengan beberapa informan, ditemukan bahwa masih terdapat perbedaan dalam menyikapi pesan yang ingin disampaikan para pimpinan tersebut, yaitu pelaksanaan program monitoring dan evaluasi pelaksanaan anggaran sebagai salah satu unsur yang penting untuk mencapai visi dan misi organisasi Direktorat PA.

Perbedaan persepsi dan pemikiran terhadap program monitoring dan evaluasi pelaksanaan anggaran masih terlihat diantara pegawai Direkorat PA. Masih terdapat pelaksana yang memiliki pemahaman yang berbeda dengan pemikiran pimpinan terkait pelaksanaan kegiatan SR dan EPA $\mathrm{K}$ atau L (Spending Review dan Evaluasi Pelaksanaan Anggaran Kementerian atau Lembaga) yang merupakan perwujudan dari program monitoring dan evaluasi pelaksanaan anggaran. Dalam wawancara, informan 1 menyampaikan pandangannya bahwa direktur sebagai pimpinan organisasi memberikan kesan bahwa kegiatan SR dan EPA $\mathrm{K}$ atau L hanya merupakan kegiatan yang tidak memiliki perbedaan dari kegiatan lain yang ada di Direktorat PA. Selain itu, pemahaman tentang penjabaran visi dan misi organisasi sebagaimana yang dimaksudkan oleh Direktur PA masih belum dimiliki oleh informan tersebut. Hal yang senada juga terlihat dari penyataan oleh informan 2 berikut ini, "yang diperlukan itu koordinasi dengan direktorat jenderal lain.. jadi dalam artian itu, mungkin hasil dari spending review itu sama direktorat jenderal 
anggaran itu jangan cuma sebagai angin lalu, gitu." Informan menyampaikan bahwa dirinya sebagai pelaksana melihat bahwa pelaksanaan kegiatan SR masih belum memberikan efek yang siginifikan dalam proses pelaksanaan anggaran Kementerian atau Lembaga karena hasil laporan SR yang belum dimanfaatkan secara maksimal oleh instansi lain yang terkait.

Penyataan kedua pegawai diatas bertentangan dengan pernyataan Direktur PA bahwa Direktorat PA memiliki peran dan fungsi yang strategis dalam menjaga pelaksanaan APBN yang diwujudkan salah satunya dengan pelaksanaan kegiatan SR dan EPA K atau L. Adanya perbedaan persepsi tersebut menandakan pesan direktur tentang pencapaian visi dan misi organisasi tidak sampai kepada bawahan yaitu pelaksana. Faktor lain yang menjadi penyebab adanya perbedaan pandangan terhadap pelaksanaan kegiatan SR dan EPA $\mathrm{K}$ atau $\mathrm{L}$ diperoleh dari hasil wawancara dengan informan 3 , yang memberikan infomasi bahwa dirinya sebagai kepala seksi merasa bahwa pegawai di level pelaksana seharusnya sudah mengetahui pentingnya pelaksanaan kegiatan SR dan EPA K atau L. Permasalahan yang muncul adalah terdapat pelaksana yang ketika menyelesaikan suatu tugas atau pekerjaan tidak melihat latar belakang dari pekerjaan tesebut, tapi lebih melihat kepada beban kerja yang harus mereka selesaikan. Ini menyebabkan pelaksana lebih concern terhadap bagaimana menyelesaikan pekerjaan mereka, bahwa penyelesaian pekerjaan hanya sebatas untuk memenuhi kewajiban sebagai pegawai, dan kurang memperhatikan apa manfaat dan pentingnya hasil pekerjaan yang dihasilkan. Tidak mengetahui apa pentingnya pekerjaan yang dilakukan juga dapat menurunkan motivasi dari pegawai yang melakukan pekerjaan, seperti pernyataan Herzberg (dalam Ruliana, 2014) terkait faktor-faktor yang dapat mempengaruhi motivasi dalam organisasi diantaranya adalah tanggung jawab, pekerjaan itu sendiri, dan potensi bagi pertumbuhan pribadi. Bila faktor ini tidak ada di tempat kerja maka karyawan akan kekurangan motivasi, namun tidak berarti tidak puas dengan pekerjaan mereka.

Hambatan lain yang ditemui dalam proses komunikasi di Direktorat PA adalah terbatasnya praktik sharing informasi dari pihak manajemen kepada bawahan atau para pegawai staf. Dalam kesehariannya, Direktur PA lebih cenderung menggunakan komunikasi secara lisan tatap muka dengan bawahannya dalam kehidupan berorganisasi di Direktorat PA. Metode komunikasi ini dipilih karena direktur merasa lebih interaktif dan efisien untuk berbicara langsung dengan anggota organisasi sebagai penerima pesan. Ketika menggunakan metode komunikasi secara lisan tersebut, direktur menerapkan tiga jenjang penyampaian pesan dan informasi kepada bawahan. Jenjang komunikasi pertama adalah dengan para kepala subdit melalui rapat rutin setidaknya dua kali dalam seminggu. Jenjang komunikasi yang kedua adalah dengan para kepala subdit dan kepala seksi melalui media pertemuan rutin morning call setiap hari Senin pagi dan yang terakhir adalah komunikasi dengan 


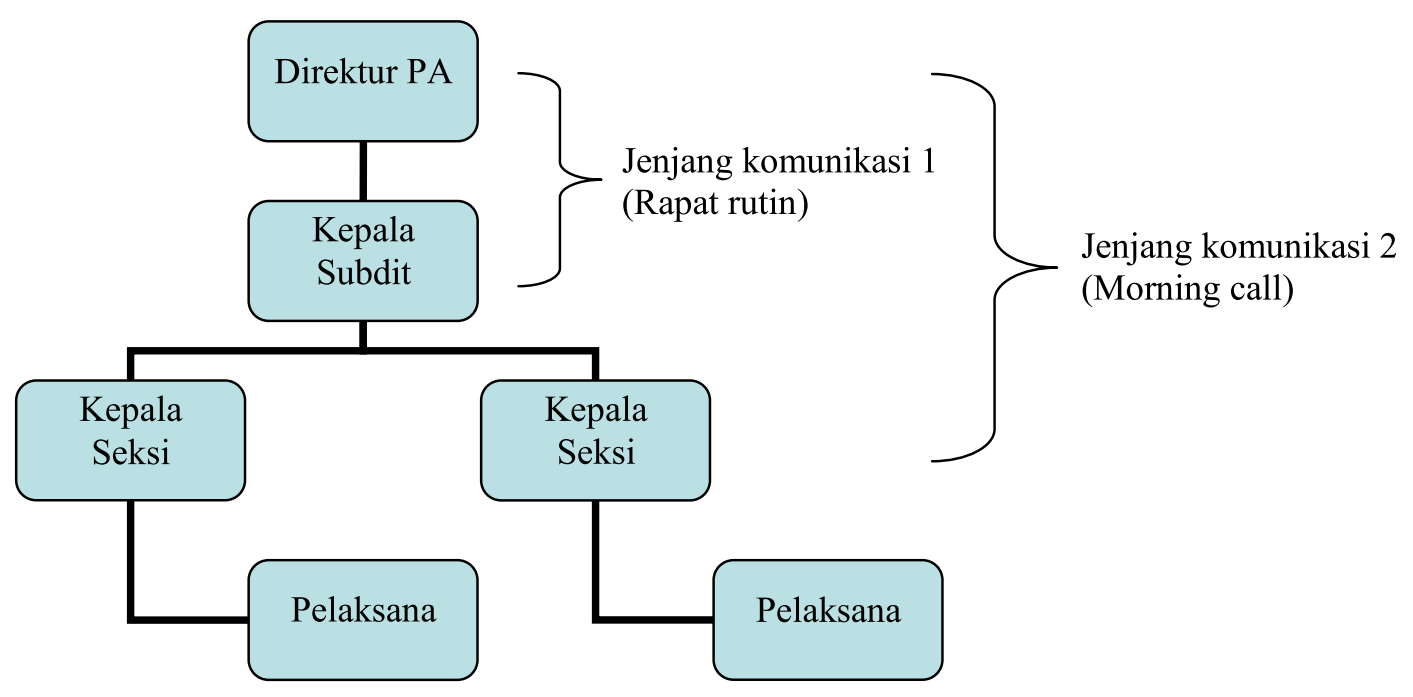

Gambar 1. Jenjang Komunikasi Direktur Pelaksana Anggaran

Sumber: Dwi Harivarman, Hasil Penelitian 2017

para pelaksana.

Jenjang informasi pertama dan kedua menjadi sangat penting karena pada jenjang tersebut direktur memberikan arahan-arahan dankebijakan terkaitpelaksanaananggaran dan tupoksi organisasi Direktorat PA, sedangkan komunikasi yang dilakukan direktur langsung kepada para pelaksana jarang terjadi karena hanya bersifat insidental. Pelaksana sebagai pegawai juga memerlukan informasi dari pimpinan organisasi, sebagaimana yang dinyatakan Pace dan Faules (2015) bahwa para pegawai di seluruh tingkat dalam organisasi merasa perlu untuk diberi informasi. Disinilah peran kepala subdit dan kepala seksi menjadi penting untuk dapat menyampaikan kembali apasaja instruksi, informasi, dan arahan dari direktur. Permasalahan muncul ketika kepala subdit tidak menyampaikan sepenuhnya informasi tersebut sehingga pelaksana tidak sepenuhnya memahami latar belakang dari kebijakan yang dikeluarkan oleh direktur, seperti yang dinyatakan informan 2 ketika ditanya terkait penjelasan perubahan jadwal pelaksanaan kegiatan SR dan EPA K atau L yang disampaikan oleh kepala subdit.

Informan 2 menyampaikanbahwakepala subdit tidak memberikan penjelasan terkait perubahan jadwal pelaksanaan kegiatan dan hanya langsung menyampaikan jadwal yang baru sesuai nota dinas serta instruksi agar pekerjaan tersebut harus cepat diselesaikan. Tidak adanya penjelasan tersebut membuat pelaksana merasa kalau kegiatan tersebut dilaksanakan secara mendadak sehingga berpengaruh terhadap hasil laporan SR dan EPA $K$ atau $L$ yang tidak maksimal. Hal tersebut disampaikan oleh informan 2 melalui pernyataan sebagai berikut, “... tetep lah dadi problem, dalam artian kan, ketika nota dinas berlaku surut, spending reviewnya kan kurang efisien..dalam artian, nilai-nilai inefisiensi ataupun duplikasi itu nggak 100\% ketemu, jadi nggak 100\% lah..”. Pernyataan tersebut menandakan bahwa hasil laporan SR yang dihasilkan pelaksana menjadi kurang maksimal karena tidak ada penjelasan terkait perubahan jadwal pelaksanaan kegiatan.

Terbatasnya praktik sharing informasi 
juga dapat terjadi karena adanya dua jenjang komunikasi pada pejabat di level manajerial yang menyebabkan informasi yang bersumber dari direktur sudah melalui dua kali penyaringan terlebih dahulu sebelum sampai kepada pelaksana. Ini menyebabkan pesan atau informasi tersebut memiliki kemungkinan untuk mengalami perubahan makna, baik itu disebabkan oleh penambahan ataupun pengurangan informasi. Dari hasil wawancara dengan informan 1, diketahui terdapat kemungkinan adanya perubahan makna pesan atau informasi dari direktur ketika pesan tersebut disampaikan oleh kepala subdit kepada kepala seksi, dan dari kepala seksi kepada pelaksana. Dalam proses jalannya informasi dari atas ke bawah tersebut dapat terjadi miskomunikasi diantara pejabat di level manajerial yang menyebabkan pelaksana dalam satu unit yang sama dapat menerima instruksi yang berbeda, sehingga membuat hasil pekerjaan yang dihasilkan juga berbeda. Kemungkinan terjadinya perbedaan informasi tersebut menjadi semakin besar jika terdapat perbedaan juga dalam memaknai pesan tersebut oleh para pejabat di level manajerial. Proses mengalirnya informasi dari pimpinan kepada bawahan merupakan akivitas yang sulit dan berkesinambungan. Pace dan Faules (2015: 186) menyampaikan bahwa pemilihan cara menyediakan informasi tidak hanya mencakup pengeluaran sumber daya langsung moneter tetapi juga sumber daya psikis dan emosional.

Faktor lain yang dapat menjadi kendala dalam pelaksanaan strategi komunikasi Direktorat PA adalah gaya kepemimpinan dari atasan kepada bawahan dalam organisasi. Hal tersebut terlihat dari pernyataan yang disampaikan informan 1, bahwa sosok Direktur PA merupakan pimpinan yang otoriter dan kurang dapat mengakomodir pendapat dari bawahan terutama dari pelaksana terkait suatu pekerjaan atau pelaksanaan kegiatan. Anggapan tersebut muncul diantaranya ketika pelaksanaan kegiatan SR dan EPA $\mathrm{K}$ atau L, dimana kegiatan tersebut yang semula dijadwalkan dilaksanakan pada bulan Februari namun oleh Direktur PA dimajukan menjadi bulan Januari. Perubahan jadwal pelaksanaan kegiatan tersebut dirasakan informan Puguh sangat mendadak dan tanpa adanya diskusi dahulu dengan pegawai di masing-masing Subdit Pelaksanaan Anggaran, sehingga hal tersebut dapat membuat semangat bawahan dalam menyelesaikan pekerjaan menjadi menurun.

Pendapat yang senada juga disampaikan oleh informan 4 dalam wawancaranya, bahwa Direktur PA dalam melakukan komunikasi dapat menjadi sangat disiplin dan terkadang sangat keras ketika menyampaikan arahan. Keras dalam artian nada intonasi yang meninggi pada saat menyampaikan arahan kepada bawahan seperti kepala subdit dan kepala seksi. Berdasarkan hasil wawancara dengan kedua informan tersebut diatas diketahui bahwa gaya kepemimpinan yang ditunjukkan oleh direktur tersebut membuat bawahan merasa kurang nyaman dalam melaksanakan kegiatan atau menyelesaikan pekerjaan. 
Pelaksana melaksanakan tugasnya dengan dibayangi rasa khawatir yang membuat pelaksana menyelesaikan pekerjaan sesuai dengan batas waktu yang ditentukan namun kualitas hasil pekerjaan kurang maksimal, seperti yang disampaikan oleh informan1 dalam wawancaranya dengan peneliti.

Gaya kepemimpinan yang kurang sesuai dengan preferensi pelaksana tidak hanya ditunjukkan oleh direktur tetapi juga oleh pejabat di level manajerial seperti kepala subdit. Terdapat kepala subdit yang memfilter informasi yang berasal dari direktur ketika disampaikan kepada bawahan di unitnya masing-masing. Terkait pelaksanaan kegiatan SR dan EPA K atau L, informasi latar belakang mengapa jadwal pelaksanaan kegiatan tersebut dimajukan tidak disampaikan oleh kepala subdit kepada bawahan. Hal ini mengakibatkan bawahan khususnya pelaksana dalam melaksanaan kegiatan hanya sekedar untuk memenuhi perintah yang disampaikan oleh atasan, tanpa ada pemahaman mengenai pentingnya jadwal pelaksanaan kegiatan tersebut harus dimajukan dari rencana sebelumnya. Temuan ini disampaikan oleh informan 2, yang menyatakan dia menyelesaikan pekerjaannya hanya karena memang itu adalah perintah atasan, tanpa memahami sepenuhnya pentingnya pengajuan jadwal pelaksanaan kegiatan tersebut.

Hambatan atau kendala dalam komunikasi secara internal yang dialami Direktorat PA sesuai dengan hambatan dalam berkomunikasi yang disampaikan oleh Ron Ludlow dan Fergus Panton(1996: 13). Adanya perbedaan persepsi antara atasan dan bawahan disebabkan oleh perceptual distortion yaitu perbedaan dalam cara pandang dan cara berpikir antara komunikator dan komunikan pada saat proses komunikasi. Hal ini terlihat dari perbedaan pernyataan yang diberikan oleh pegawai di level pelaksana dengan pernyataan direktur terkait pelaksanaan kegiatan SR dan EPA K atau L. Kendala berupa pembatasan dalam informasi yang disampaikan oleh atasan kepada pelaksana serta gaya kepemimpinan atasan yang tidak sesuai dengan preferensi bawahan merupakan distorsi yang disebabkan adanya status effect yaitu adanya perbedaan status sosial di antara anggota organisasi yang memiliki status yang lebih tinggi dalam jenjang hierarki atau struktur organisasi dibandingkan dengan anggota yang lain. Direktur sebagai pimpinan tertinggi organisasi Direktorat PA telah menentukan pola komunikasi dengan bawahan melalui penjenjangan informasi yang ternyata menyebabkan informasi yang mengalir ke bawah terutama ke level pegawai pelaksana menjadi tidak utuh. Hal tersebut disebabkan adanya kepala subdit yang tidak sepenuhnya menyampaikan informasi terkait pekerjaan kepada bawahan. Tidak utuhnya informasi tersebut berperan salah satunya dalam membuat hasil pekerjaan dari bawahan menjadi tidak maksimal.

Pengaruh dari adanya status effect juga terlihat dari gaya kepemimpinan direktur dalam memimpin bawahan yang dianggap bawahan terkesan otoriter. Direktur juga dianggap kurang dapat mengakomodir pendapat yang disampaikan oleh bawahan namun di sisi lain mengharapkan bawahan menyelesaikan pekerjaan dengan cepat dan maksimal, tanpa memberikan penjelasan yang memadai terkait pelaksanaan kegiatan. Gaya kepemimpinan atasan yang terkesan otoriter serta cara atasan dalam memberikan informasi kepada bawahan juga disebabkan adanya cultural differences antara atasan dan 
bawahan, yaitu perbedaan dalam budaya, lingkungan, dan pengalaman sosial yang membuat atasan memiliki perbedaan dengan pelaksana dalam penyampaian informasi serta dalam bersosialiasi dalam organisasi. Sosok direktur dan kepala subdit sebagai atasan memiliki pengalaman kerja yang lebih lama daripada para bawahan serta telah berada di lingkungan kerja yang beragam selama menjadi pegawai. Pengalaman yang dimiliki tersebut berkontribusi dalam bagaimana cara direktur dan kepala subdit menjalankan perannya sebagai atasan yang ternyata menjadikan adanya perbedaan dalam cara atasan menyampaikan informasi kepada bawahan serta dalam gaya kepemimpinan ketika menjalankan pekerjaan.

Hambatan dalam organisasi tersebut juga sesuai dengan gangguan komunikasi yang sering muncul dalam komunikasi organisasi menurut Warren R. Plunket dan Raymond F. Atner (dalam Ruliana, 2014) yaitu gangguan komunikasi di tingkatan manajemen (management level), bahwa di dalam tingkatan manajemen organisasi dapat terjadi penyampaian pesan atau informasi yang tidak sepenuhnya berlangsung dengan lancar, baik ditinjau dari arah atau aliran informasi atau pola komunikasi, baik secara top down maupun bottom up. Hambatan komunikasi lainnya yang kerap muncul adalah berupa manager interpretation (interpretasi manajer), yaitu masing-masing manajer memiliki pola pikir, pola berhubungan dan cara penafsiran yang berbeda-beda ketika berinteraksi dengan bawahan. Hal ini ditunjukkan dengan adanya pejabat di level manajerial Direktorat PA yang memaknai informasi yang disampaikan oleh direktur dan atau kepala subdit dengan cara yang berbeda. Perbedaan tersebut membuat informasi yang disampaikan kepada pegawai pelaksana menjadi berbeda sehingga dapat menyebabkan ketidakseragaman dalam hasil pekerjaan.

\section{Simpulan}

Hambatan komunikasi pasti akan selalu terjadi dalam setiap proses komunikasi dalam organisasi, tak terkecuali pada organisasi pemerintahan ketika menjalankan suatu program atau kegiatan. Hasil dari penelitian menunjukkan bahwa Direktorat PA Kementerian Keuangan sebagai organisasi pemerintahan menghadapi beberapa hambatan komunikasi internal dalam pelaksanaan Program Monitoring dan Evaluasi Pelaksanaan Anggaran, yaitu adanya perbedaan persepsi antara pimpinan dan bawahan terhadap pelaksanaan kegiatan dan program yang termasuk dalam perceptual distortion, terbatasnya praktik sharing informasi dari pihak manajemen kepada pegawai pelaksana dan pengaruh gaya kepemimpinan atasan dalam pelaksanaan kegiatan yang disebabkan adanya status effect dan cultural differences dalam organisasi Direktorat PA.

Dalam rangka memperoleh komunikasi yang efektif untuk kelancaran pelaksanaan program dankegiatan di masayang akan datang, Direktorat PA Kementerian Keuangan perlu menerapkan beberapa strategi komunikasi untuk meminimalisir hambatan-hambatan yang dihadapi tersebut. Pimpinan dan pejabat Direktorat PA di tingkat manajerial perlu lebih aktif dalam menanamkan gagasan visi dan misi organisasi kepada para pegawai khususnya di level staf atau pelaksana. Kemudian organisasi perlu menciptakan mekanisme berbagi informasi dan pengetahuan (information and 
knowledge sharing culture) sampai ke level staf atau pelaksana.

Hasil dari penelitian ini diperoleh dengan beberapa keterbatasan. Data hanya diperoleh dari satu institusi pemerintah saja dan bersifat data kualitatif. Untuk meningkatkan reliabilitas hasil penelitian, jumlah sampel data perlu diperbanyak dengan menambah subyek penelitian yaitu beberapa institusi pemerintah. Selain itu, data secara kuantitatif juga perlu diperoleh untuk menambah kekayaan hasil penelitian. Penelitian selanjutnya dapat dilakukan untuk mengetahui strategi apa yang dapat diterapkan oleh organisasi pemerintahan untuk mengatasi hambatanhambatan komunikasi yang terjadi secara internal organisasi. Selain itu, dapat dilakukan kajian lebih lanjut mengenai budaya berbagi informasi dan pengetahuan (information and knowledge sharing culture) dalam organisasi pemerintahan.

\section{Daftar Pustaka}

Effendy, Onong Uchjana. (2011). Ilmu Komunikasi: Teori dan Praktek. Bandung: PT Remaja Rosdakarya.

Johanna, Pricillia. (2013). Hambatan Downward Communication antara Pimpinan dan Karyawan PT Makmur Jaya. Jurnal E-Komunikasi. Volume 2. Hlm. 25-37.

Laporan Spending Review Tahun 2015. (2015). Jakarta: Direktorat Pelaksanaan Anggaran Kementerian Keuangan.

Ludlow, R. \& Panton, F. (1996). The Essence of Effective Communication (Komunikasi Efektif) (terjemahan Deddy Jacobus). Yogyakarta: Andi.

Malo, M. \& Trisnaningtias, S. (1996). Metode Penelitian Masyarakat. Universitas Indonesia: Pusat Antar Universitas Ilmuilmu Sosial.
Marshall, C. \& Rossman, G. B. (1995). Designing Qualitative Research. California USA: SAGE Publications.

Muhammad, Arni. (2011). Komunikasi Organisasi. Jakarta: Bumi Aksara.

Monique, H., Hutter. I, \& Bailey, A. (2011). Qualitative Research Methods. USA: Sage Publications.

Pace, R. W. \& Faules, D. F. (2015). Komunikasi Organisasi: Strategi Meningkatkan Kinerja Perusahaan (Editor: Deddy Mulyana). Bandung: PT Remaja Rosdakarya.

Peraturan Menteri Keuangan Republik Indonesia Nomor 234 tentang Organisasi dan Tata Kerja Kementerian Keuangan. (2015). Jakarta: Direktorat Pelaksanaan Anggaran Kementerian Keuangan.

Rivai, Veithzal. (2008). Kepemimpinan dan Perilaku Organisasi. Jakarta: Raja Grafindo Persada.

Sarwani. (2015). Pengaruh Gaya Kepemimpinan dan Strategi Komunikasi Sekda terhadap Kinerja Pegawai di Sekretariat Daerah Provinsi Kalimantan Selatan. Jurnal Penelitian Pers dan Komunikasi Pembangunan. Volume 19. Nomor 1. Hlm. $35-46$.

Syasyikirana, Wisyesa. (2013). Strategi Komunikasi Organisasi antara Atasan dan Bawahan Pasca Restrukturisasi Manajemen (Studi Kasus pada DetEksi Jawa Pos). Jurnal Media Commonline. Volume 2. Nomor 1.

Direktorat Pelaksanaan Anggaran. (2015). Cahaya Spending Review. Diperoleh dari (http: atau atau www.djpbn.kemenkeu. go.id atau portal atau id atau berita atau 131-artikel-ulasan-opini atau 1737-cahayaspending-review.html).

Yin, K. Robert. (2014). Studi Kasus Desain dan Metode. Jakarta: Rajawali Pers. 